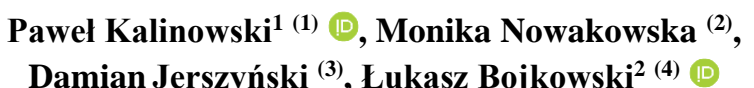

\title{
The level of Polish youth champions' temperamental qualities in football
}

(1) Department of Theory and Methodology of Team Sports Games, Poznan University of Physical Education

(2) Department of Theory of Sport, Poznan University of Physical Education

(3) Department of Swimming and Water Rescue, Poznan University of Physical Education

(4) Department of Psychology, Poznan University of Physical Education

\begin{abstract}
There are many factors which contribute to a successful sports career in football. One of the most important ones is players' comprehensive preparation which consists of motor, technico-tactical and psychical components. The study focuses on a selected psychical aspect and more precisely on the temperamental features that describe and explain relationship between a man and environment.

The aim of the study was to determine and compare the level of highly qualified young footballers' temperamental properties in relation to those of the average people of the same age. The subject of the research was 31 players of the Lech Poznań club (Polish champions U-17 from 2016). The research was carried out using the EAS-D questionnaire which consists of five scales: dissatisfaction, fear, anger, activity and sociability.

In the conducted study, there was a statistically significant differentiation of the results between the respondents and the average people at the level of two temperamental traits such as fear (a lower score in football players) and activity (a higher score in tested football players compared to the average people of the same age).
\end{abstract}

Keywords: temperament, football, sports training, EAS-D

\section{Introduction}

Training as a long-term educating process is the main research object in many fields of science, including among others physiology of physical exercise, biomechanics and biochemistry. Many methods from various scientific disciplines are used to stimulate sports development. Psychological knowledge (meaning temperamental) is also used

\footnotetext{
${ }^{1}$ dr Paweł Kalinowski, e-mail: pawel.kalinowski1030@gmail.com, ORCID: 0000-0002-7288-7208

${ }^{2}$ dr Łukasz Bojkowski, ORCID: 0000-0003-3777-0845
} 
which allows people to consciously participate in training, to control their emotions and behaviours in order to thoroughly prepare for a training or a competition as well as to endure treatment after an acquired injury and quickly recover.

Many researchers perceive temperament as a biologically conditioned construct that has an impact on human functioning, description and explanation of life and situational behaviors. It can be assumed that temperament regulates a man's relationship with external environment. (Tomczak 2013). Strelau (1985, pp. 266) wrote about it defining temperament as "relatively permanent biologically determined features of the organism. They manifest themselves in formal behavioral traits that boil down to the energy level and the time characteristics of the reaction."

Therefore, currently more and more studies refer to the temperamental predispositions to practice sports and the significance of temperament in sport activity at the level of competition, which is characterised by such situational dimensions as: maximization, social perception, competition, long-term training or physical activity (Gracz 1998).

\section{Selected temperament research}

The first data on temperament research is determined for the period of antiquity. For decades, knowledge about personality psychology has been extended by psychologists who, while conducting research and observations, created new theories, types and definitions complementing the branch of knowledge they chose. Thus, the division and definition of temperament over the years was presented through many psychological approaches. For example, Scheldon (1942) created a constitutional concept with the division into somatotomy, wiscerotony, and cerebrotonia. Allport, Mehrabian, Goldsmith and Campos showed temperamental traits within emotionality (Strelau 2000). Longitudinal research was conducted among others by Kagan (1994) who after many years of experience became an advocate of the theory of constancy, inheritance and invariability of temperament.

In 1956, American psychiatrists Chess and Thomas began to study temperament, which they defined as a style of behavior (Strelau 2004). The study was carried out as a part of the 34-year-long American research project "New York Longitudinal Study" (NYLS), the so-called "New York Longitudinal Study" which revealed tree types of temperament (including nine temperamental traits) such as light, slow to warm up and difficult. In spite of the prevailing beliefs, Chess and Thomas drew attention to the significance of particular differences in an individual's behavior and to the importance of the interaction of their individual characteristics with the environment (Strelau 1998).

Biological personality theory refers to the temperament of "PEN" Hans Eysenck which was shaped under the influence of Pavlov's concept of stimulation and inhibition (Strelau 2006). It assumes that temperament has a biological basis and temperament features are universal. Thus, the structure of temperament can be described with the help of several independent superior factors: extraversion (sociability, briskness and assertiveness), neuroticism (anxiety, depression and guilt) and psychoticism (aggression, egocentrism and impulsiveness) which are further 
referred to as super-factors, main dimensions, or biological dimensions (Strelau 1998). Eysenck created his theory on the basis of historical sources, namely on the works of Hippocrates-Galen, Wundt, Jung, Gross and Heysmans-Wiersma (Strelau 1998).

According to Strelau, temperament is innate and shows variation in ontogenesis under the influence of selected environmental factors (which must be long or intense) which is common for humans and animals (Zawadzki, Strelau 1997). According to the Regulatory Theory of Temperament created by him, this construct (manifested in all activities) can be treated as an instruction that regulates the strength and speed of psychological and psychomotor phenomena (Gracz, Sankowski 2007) and, therefore, allows to determine formal features behavior, based on two components such as energy level (characteristic for the individual ways of storing and discharging energy) and time response characteristics (Gracz, Sankowski 2007).

In the energy level of behavior "determined by individual differences in the physiological mechanisms responsible for the energy level of the organism" (Zawadzki, Strelau 1997, pp. 16) four basic features were distinguished:

1. Reactivity (RE) - means "the tendency to react intensively to stimuli that evokes emotions, expressed in a high sensitivity and a low emotional immunity" (Gracz, Sankowski 2007, pp. 312). "The weaker the stimulus causing a barely perceptible reaction is" (Gracz, Sankowski 2007, pp. 308), the bigger reactivity and the greater the sensory sensitivity are.

2. Behavioral activity (AK) - "a tendency to take behavior with a high stimulus value, or to behaviors that provide strong external stimulation" (Gracz, Sankowski 2007, pp. 312).

3. Sensory Sensitivity (WS) - "the ability to respond to sensory stimuli of a low stimulus value”. (Gracz, Sankowski 2007, pp. 311). Sensitivity is directly related to emotional reactivity.

4. Endurance (WT) - "the ability to adequately react in situations requiring longlasting or highly stimulatory activity and / or in conditions of strong external stimulation" (Gracz, Sankowski 2007, pp. 312).

The second component of temperament is a set of elements characterizing the course of reaction in time (Gracz, Sankowski 2007), ie the so-called time aspects (temporal behavioral characteristics) (Strelau 2006). The verification revealed the legitimacy of creating two basic time characteristics, which include:

1. Liveliness (LV) - "a tendency to react quickly, to maintain a high rate of activity and to easily change from one behavior (reaction) to another, corresponding to changes in the environment" (Gracz, Sankowski 2007, pp. 311). This temperament feature may manifest itself in a faster possibility of changing the ways of a voltage discharge, and in a quicker adaptation to changing conditions.

2. Perseverance (PE) - "the tendency to continue and repeat behaviors after cessation of the stimulus (situation) that causes this behavior" (Gracz, Sankowski 2007, pp. 311).

Buss and Plomin (1984) drew attention to the biological basis of temperament, which is to be associated with inheritance. In their concept of temperament, they stressed that "temperaments are the inherited personality traits from the early childhood" (Buss, Plomin 1984, pp. 84). They also created an EAS 
theory that is an acronym of three traits that are to be included in the characteristics of temperament: emotionality, activity and sociability.

1. The first trait (emotionality) has been described as a reaction of strong excitation manifested in the form of dissatisfaction, fear and anger (Strelau 2000).

2. Activity was defined as "two correlated components: vigor, manifested in the energy level of behavior, and the rate expressed in reaction speed" (Strelau 2000, pp. 703).

3. The third feature (sociability) is described as a social relation having a positive meaning for human functioning which is one of the components of extraversion (Buss, Plomin 1984).

Szwarc (2003) wrote about the role of temperament in sporting activity which while characterizing a high-class player indicated the need for him to have an optimal level of temperamental factors. Arguing the need to study temperamental profiles of players, one can point to the characteristics of a football game, which is a subject-matter situation subjected to constant evaluation. In this sense, the higher the level of sport a given player presents, the faster and more the expectations and expectations grow. This is accompanied by adequately greater emotions and more and more pressure (internal and external) which may lead to a higher level of fear or dissatisfaction. Therefore, it is highly probable that one of the factors affecting the sports potential of football players, their level of adaptation and functioning in conditions of competition, are certain temperamental properties that are a moderator between the individual and the external environment.

Based on the presented theoretical approaches, the aim of the work was defined, which is the characteristics of the level of five temperamental traits of young players of Lech Poznań (Polish champions U-17) measured by the EAS-D questionnaire. The following research questions have been formulated adequately to the stated objective:

1. What is the level of dissatisfaction (temperamental traits) in the youth champions of Poland against the background of the average people?

2. What is the level of fear (temperament traits) in the athletes surveyed against the background of the average people?

3. What is the level of anger (temperamental traits) in the tested players of Lech Poznan against the background the average people?

4. What is the level of activity (temperament traits) in young players of the Polish champion against the background of the average people?

5. What is the level of sociability (temperamental traits) in the tested players against the background of the average people?

\section{Materials and methodology}

The research group consisted of 31 youth representatives of the Lech Poznan football club (U-17). The surveyed players represented the highest sports level which they confirmed by winning the Polish championship in 2016 in the junior junior category. The average age of the respondents was 17 years $(\mathrm{SD} \pm 1$ year). 
The research was carried out by means of a diagnostic survey using the EASD temperament questionnaire of Buss and Plomin (1984) in the Polish adaptation Oniszczenko (1997). The adult version of the questionnaire includes five factors, namely: dissatisfaction, fear, anger (all three are features that show a tendency to use emotions of so-called emotionality), activity and sociability. The acceptance of the Polish Psychological Association was received for the use of the questionnaire. The statements contained in the questionnaire were closed with a 5-point Likert scale (from 1 - "definitely not" to 5 - "definitely yes"). The theoretical basis of the tool is the Genetic Temperament Theory A.H. Bussa and R. Plomin.

\section{Results}

In the first place, the individual results obtained were presented using a sten scale. Then, they were developed using selected methods of descriptive statistics, e.g. an average value, a standard deviation and a standard error. The existence of differences between the tested footballers and the people from the comparison group was determined using the Student's t-test. The mean for the general population on the sten scale was $\mathrm{M}=5.5$, a standard deviation $\mathrm{SD}=2$.

Tab. 1. Comparison of the level of temperamental traits of Lech Poznań players with the average value of the normalization sample

\begin{tabular}{lccccccccc}
\hline & \multicolumn{7}{c}{ Test of averages against a fixed reference value } \\
Variable & \multicolumn{7}{c}{ (Lech Poznań U-17) } \\
\cline { 2 - 10 } & Mean & SD & Important & SE & $\begin{array}{c}\text { Reference } \\
\text { Constant }\end{array}$ & t & df & p \\
\hline Dissatisfaction & 5,16 & 1,29 & 31 & 0,23 & 5,50 & - & 30 & 0,155 \\
Fear & $\mathbf{5 , 0 0}$ & $\mathbf{1 , 2 4}$ & $\mathbf{3 1}$ & $\mathbf{0 , 2 2}$ & $\mathbf{5 , 5 0}$ & - & $\mathbf{2 , 2 5}$ & $\mathbf{3 0}$ & $\mathbf{0 , 0 3 2}$ \\
Anger & 5,74 & 1,75 & 31 & 0,31 & 5,50 & 0,76 & 30 & 0,448 \\
Activity & $\mathbf{6 , 1 3}$ & $\mathbf{1 , 5 2}$ & $\mathbf{3 1}$ & $\mathbf{0 , 2 7}$ & $\mathbf{5 , 5 0}$ & $\mathbf{2 , 3 0}$ & $\mathbf{3 0}$ & $\mathbf{0 , 0 2 8}$ \\
Sociability & 5,52 & 1,86 & 31 & 0,46 & 5,50 & 0,27 & 30 & 0,791 \\
\hline
\end{tabular}

Analyzing the level of temperamental properties in the tested players of the Polish champion team, no differences were noted in relation to the normalization group in the dimension of dissatisfaction, anger and sociability. However, a lower level of fear $(\mathrm{t}=-2.25, \mathrm{df}=30, \mathrm{p}<0.05)$ and a higher level of activity $(\mathrm{t}=2.30, \mathrm{df}=$ $30, \mathrm{p}<0.05)$ compared to the group standardization were observed.

\section{Discussion}

The increasing level of requirements for footballers puts more and more demands on the identification of talent and recognition of the players' predisposition to competition. Therefore, it can be assumed that comprehensive preparation of players 
is necessary to achieve success in the disciplined sport. Therefore, in this work attempts have been made to determine the level of temperamental traits distinguished by Buss and Plomin (1984), which are relatively constant and form the basis for shaping and developing personality.

Considering the structure of temperament characterizing the research group in relation to the normalization group, there were no statistically significant differences in the dimension of dissatisfaction and anger (two traits related to emotionality), as well as sociability. This means that professional footballers are not characterized by a greater or lesser tendency to react easily and strongly with greater anxiety, as well as a tendency towards negativism (Oniszczenko 1997) in comparison to the average people. They also do not show a difference in the dimension of looking for other people, avoiding loneliness, frequency of social contacts and reactions to isolation (Strelau 2000).

However, a statistically significant difference was observed in the case of activity and fear. Activity which is related to the energy expenditure also determines the style of behavior. In other words, higher activity may lead to making behavioral efforts characterized by a high physical energy expenditure which is understood as the number of movements performed per unit of time and / or high intensity (Oniszczenko 1997; Gracz, Sankowski 2007). It is, therefore, determined that the youth surveyed Polish football champions are characterized by a higher pace and speed of action, as well as a greater vigor (intensity of reaction) than the avarage people. It is worth noting that a high level of activity can have a positive effect on the player's adaptation to specific conditions during the game. Football is characterized by high variability of conditions and activities during a competition.

The lower level of fear (one of the constituent emotionalities) in professional football players, however, indicates a lower tendency of young players to reactions based on escaping the threat or avoiding uncomfortable stimulation, which may be reflected in the effectiveness of the start-up activities. This is important because during the game, especially in sudden and unforeseen difficult situations which are often the same as the occurrence of high pressure from the surroundings the players may expereince a higher level of fear. Hence, it can be assumed that the low level of this trait (fear understood as a temperamental feature) may favorably affect the effectiveness of competitors during direct sporting activity.

Analysis of temperamental profiles of young football players conducted using the EAS-D Temperament Questionnaire presents the level of specific temperamental traits against the background of the avarage people. Nevetheless, it would be vital to carry out research to determine the impact of the intensity of the analyzed factors on the effects of football. In other words, the obtained test results may be a kind of determinant of the direction of searching for dependence between temperamental factors (and other psychological traits), and the direct effectiveness or efficiency of football action. 


\section{Conclusions}

1. On the basis of the research carried out in the EAS temperament questionnaire, it was found that the differences in the level of dissatisfaction, anger and sociability that were characteristic of Polish youth football champions were statistically insignificant in comparison to the general population.

2. The tested competitors were characterized by a lower level of fear and a higher level of activity compared to the people from the general population.

3 . The conducted research is a prognostic for continuing research on a larger number of respondents as well as to the effectiveness of the start-up activity.

\section{References}

Buss, A.H., Plomin, R. (1984). Temperament: Early developing personalitytraits. New York: Hillsdale. Erlbaum.

Gracz, J. (1998). Psychospołeczne uwarunkowania aktywności sportowej człowieka. Poznań: Akademia Wychowania Fizycznego.

Gracz, J., Sankowski, T. (2007) Psychologia aktywności sportowej. Podręcznik nr 58. Poznań: Akademia Wychowania Fizycznego.

Kagan, J. (1994) Galensprophecy: Temperament in humannature. New York: Basic Books.

Oniszczenko, W. (1997). Kwestionariusz temperamentu EAS Arnolda H. Bussa $i$ Roberta Plomina. Wersja dla dorostych i dzieci. Adaptacja polska. Warszawa: Polskie Towarzystwo Psychologiczne.

Sheldon, W.H., Stevens, S.S. (1942). The varieties of temperament; a psychology of constitutional differences. Oxford, England: Harper.

Strelau, J. (1969). Temperament i typ uktadu nerwowego. Warszawa: Wydawnictwo Naukowe PWN.

Strelau, J. (1985). Temperament, osobowość, działanie. Warszawa: Wydawnictwo Naukowe PWN.

Strelau, J. (1998). Psychologia temperamentu. Warszawa: Wydawnictwo Naukowe PWN.

Strelau, J. (2000) Psychologia. Podręcznik akademicki. Tom 2. Psychologia ogólna. Gdańsk: Gdańskie Wydawnictwo Psychologiczne.

Strelau, J. (red). (2004). Psychologia - podręcznik akademicki. Psychologia ogólna. Tom II. Gdańsk: Gdańskie Wydawnictwo Psychologiczne.

Strelau, J. (2006) Temperament jako regulator zachowania z perspektywy pótwiecza badań. Gdańsk: Gdańskie Wydawnictwo Psychologiczne.

Strelau, J., Zawadzki, B. (1998). Kwestionariusz Temperamentu PTS. Podręcznik. Warszawa: Polskie Towarzystwo Psychologiczne.

Szczepaniak, P., Strelau J., Wrześniewski, K. (1996). Diagnoza stylów radzenia sobie ze stresem za pomoca polskiej wersji kwestionariusza Ciss Endlera i Parkera. W: Przegląd Psychologiczny, 39, 187-210.

Szwarc, A. (2003). Metody oceny techniczno-taktycznych działań piłkarzy nożnych. Gdańsk: Akademia Wychowania Fizycznego i Sportu. 
14 | Paweł Kalinowski, Monika Nowakowska, Damian Jerszyński, Łukasz Bojkowski

Thomas, A., Chess, S. (1977). Temperament and development. Oxford, England: Brunner/Mazel.

Tomczak, M. (2013). Styl rywalizacji a efektywność działania w spotach walki analiza psychologiczna. Monografie nr 423. Poznań: Akademia Wychowania Fizycznego.

Zawadzki, B., Strelau, J. (1997). Formalna Charakterystyka Zachowania Kwestionariusz Temperamentu (FCZ-KT) Podręcznik. Warszawa: Polskie Towarzystwo Psychologiczne. 